Open Access

\title{
Can street entrepreneurs be Schumpeterian entrepreneurs? The case of food trucks as family firms in an emerging country
}

\author{
Daniele Eckert Matzembacher ${ }^{*}$ (D, Rogério Leite Gonzales and Carlos S. V. Saldanha
}

\author{
* Correspondence: \\ daniele_eckert@yahoo.com.br \\ Postgraduate Programme in \\ Management, Universidade Federal \\ do Rio Grande do Sul (PPGA/ \\ UFRGS), Porto Alegre, Rio Grande \\ do Sul, Brazil
}

\begin{abstract}
In times of economic downturn, entrepreneurship discourse returns to the forefront. In this context, in Brazil, there is a new economic and social phenomenon going on: street ventures as family firms. Once marginalized and normally related to informal work, now they perform activities in the market that allow them to offer higher quality products and to reach consumers with higher purchasing power. Aiming to better understand the phenomenon, this study explores the main aspects that characterize entrepreneurship, its motivations, knowledge and capacity for innovation. A participant observation was carried out analyzing the operation of 44 food trucks and in-depth interviews were conducted with 11 food trucks owners. Results indicate that, unlike the literature premise, the first entrant food trucks were Schumpeterian entrepreneurs. However, there was a dissemination of knowledge and they lost this condition. As a result, suggestions are presented to these entrepreneurs return to the Schumpeterian condition. This paper advances in theoretical knowledge by identifying that the Schumpeterian innovation of this street entrepreneurship is highly geographic-contextual. It possible can lead to a decrease in the risk of business failure in places in which knowledge is disseminated as innovation.
\end{abstract}

Keywords: Entrepreneurship, Food trucks, Food sector, Innovation, Knowledge dissemination, Low tech, Schumpeter, Small business

\section{Introduction}

The culture of entrepreneurship has become a buzzword throughout the business world. It celebrates autonomy and risk-taking (Doody, Chen \& Goldstein, 2016). Entrepreneurs are recognized for their posture of innovativeness, experimentation and pro-active pioneering of new markets (Zhang, Groen \& Belousova, 2018).

In entrepreneurship research, economic sociologists have focused their inquiry on profit-making, proprietorship, and business creation, including what drives individuals to start businesses and what accounts for the success and failure of new firms (Doody, Chen \& Goldstein, 2016). Researchers have also focused on how individual traits, institutional characteristics, and resource configurations influence entrepreneurial performance (Companys \& McMullen, 2007).

However, the understanding of how entrepreneurs in emerging market enhance innovation performance is still limited (Zhang, Chen \& Kane, 2018). In fact, despite

(c) The Author(s). 2019 Open Access This article is distributed under the terms of the Creative Commons Attribution 4.0 International License (http://creativecommons.org/licenses/by/4.0/), which permits unrestricted use, distribution, and reproduction in any medium, provided you give appropriate credit to the original author(s) and the source, provide a link to the Creative Commons license, and indicate if changes were made. 
the maturity of food sector, there are still relatively few studies regarding innovationrelated issues (Lefebvre et al., 2015). Most of the existent researches focus on high-tech industries (Vrontis et al., 2017). More investigations are necessary in low-tech companies, as the case of entrepreneurship in street ventures (Alfiero, et al., 2017).

The key issue facing many small medium-sized enterprises as street ventures is related to how they can foster effective innovation (Farsi \& Toghraee, 2014). There is a need to understand which factors contribute to successful innovation by entrepreneurial firms in emerging economies characterized by institutional uncertainty (Greeven \& van de Kaa, 2013). This gap exists especially because their innovative and experimentation posture may lead to more frequent innovation failures (Zhang, Groen \& Belousova, 2018).

Moreover, few studies have evaluated critically the explanations for participation in street entrepreneurship activities (Williams \& Gurtoo, 2012). It is necessary to understand how economic actors purposefully enact new opportunities to create innovation in a variety of industry environments (Companys \& McMullen, 2007). Scholars have yet to develop a full understanding that explains the emergence and development of entrepreneurial opportunities. It is necessary to better understand the relationship between opportunity, innovation, performance and the strategies that are needed to discover and exploit new opportunities (Companys \& McMullen, 2007).

This paper aims to address this gap, specifically at deepening knowledge of street entrepreneurship as family firms. The starting point has been the prevalent premise in the literature that, due to their low technological standards, street entrepreneurs are not innovative (Reynolds et al., 2002; Bhola et al., 2006).

The question that guided this investigation is: How do street entrepreneurs discover and exploit opportunities in the low-tech food industry? And how can street entrepreneurs be Schumpeterian Entrepreneurs? To answer these questions an investigation was carried out with the case of food trucks as family firms in an emerging country. An effort was made in order to investigate the main elements behind this economic and social phenomenon, bringing forth concepts and practices that enable progress in the knowledge in order to create insights for future research.

It is hoped to contribute to the existing knowledge about street entrepreneurship by developing a better view of the nature and characteristics of entrepreneurial opportunities, as well as the strategies that should be employed to discover and exploit these opportunities. Specially, it is expected to contribute in the understanding of how street entrepreneurs can innovate in times of crises lowering failure risks.

This study presents relevance at a time when many countries are facing economic downturn and global changes in job dynamics, while the entrepreneurship discourse (or disguised self-employment entrepreneurship) returns to the forefront. Against this backdrop, a new phenomenon related to street entrepreneurship sparked research interest: street ventures, once marginalized and normally related to informal work, are now enjoying growing emphasis. Highly educated entrepreneurs, who otherwise would decide to open a store in a mall or a laundry franchise, are now seizing itinerant business opportunities with more flexibility, preparation and contact with the public as 
an opportunity of independence and realization. This phenomenon may give rise to new market settings and needs to be better understood. The relevance to understand the phenomena that surround an emerging country, conducting this study in Brazil, is because this country responds to the largest economy in Latin America, according to the International Monetary Fund (2017).

\section{The entrepreneur}

This term entrepreneurship can be defined at its most basic level as business creation (Doody, Chen \& Goldstein, 2016). Entrepreneurship is the result of individual innovation, passion and tenacity (Kuratko, 2011). Entrepreneurial intention relates to a composite of some demographic, competencies, networks and perception factors (Khefacha \& Belkacem, 2015). This behavior is related with attention to social, societal and personality factors, such as experience, education, economic and political climate (Ozaralli \& Rivenburgh, 2016).

Academically, there is much more than one definition of entrepreneur, as many authors have made efforts to better understand and describe the concept. The perspective adopted here is that the taxonomy of entrepreneurial theories can be classified in three major schools: a) Neoclassical of Marshall, Knight and Schultz; b) Austrian of Menger, Von Mises and Kirzner; and c) German or Schumpeterian of von Thünen, Schumpeter and Baumol (Wennekers and Thurik, 1999).

The (neo)classical stress the role of the entrepreneur in leading markets to equilibrium through their entrepreneurial activities. The Austrians concentrate on the abilities of the entrepreneur to perceive profit opportunities, usually after some exogenous shock. The "Austrian" entrepreneur combines resources to fulfil currently unsatisfied needs or to improve market inefficiencies or deficiencies. In the German or Schumpeterian tradition, economists concentrate on the entrepreneur as a creator of instability and creative destruction. The difference between the German (Schumpeterian) and Austrian tradition can be summarized as follows: according to Nooteboom (1993), the Schumpeterian entrepreneur creates the potential and the Austrian realizes it (Wennekers and Thurik, 1999).

Another widely accepted concept of entrepreneur is the one provided by the Global Entrepreneurship Monitor (GEM, 2015): entrepreneurship is any attempt to create a new venture, whether to start a new company, to expand an existing one or even to practice an autonomous activity. In this view, an entrepreneur can be related to someone sophisticated, formal enterprises and higher benefit, or to those very simple businesses, whether formal or informal, aiming only to have a different source of income, whether replacing or complementing the salary.

\section{Schumpeterian entrepreneur and innovation}

According to Schumpeter (1961), the entrepreneur is an agent of change highly related to innovation processes in companies, by inserting new products/services, new ways to produce, manage or transacting that meet market requirements. Schumpeter consider that innovation is exploring successfully new ideas. And, success, for entrepreneurs, means to increase revenues, access new markets, increase profit margins and other tangible benefits in results. Those are conditions to be a Schumpeterian entrepreneur. 
In the Schumpeterian view, there are four types of innovation: 1) Product innovation: introduction of new or significantly improved products or services in the market; 2) Process innovation: implementation of new or significantly improved production processes and logistics of goods or services; 3) Organizational innovation: implementation of new organizational methods in the practice of business, work organization and/or external relations; 4) Marketing innovation: implementation of new marketing methods involving significant improvements in product design or packaging, price, distribution and promotion.

Schumpeter (1984) states that the development of the economic system happens during changes, and the main tool that makes this possible are firms, as they have different conditions to produce innovations. Innovation is what gives "life" to any new idea (venture). Creativity, new solutions, new products, new markets, new technologies are the expected results whenever an entrepreneurial venture is in practice.

\section{Street entrepreneurs}

For the purposes of this study, it is essential to point out a very specific kind of entrepreneur - the street entrepreneur. Conceptually, one can define the street entrepreneur as someone who sells things on the street, without any physical structure built; there are only vendors working on temporary structures, improvised sites or mobile equipment (Williams, 2012).

In a broader definition, street entrepreneurs are those that start-up and/or own or manage business ventures that offer goods for sale to the public on the streets, without having any permanent built structure (Bhowmik, 2007). They are either stationary occupying space on the pavement or some other public/private space, or are mobile carrying their wares on push carts or in baskets on their heads (Gurtoo and Williams 2009).

Most of these street entrepreneurs do their practice in the informal economy (defined by the International Labour Office as an economic activity that is not covered or insufficiently covered by formal arrangements, either in law or in practice (ILO, 2002, 2011; Gurtoo and Williams 2009; Williams \& Gurtoo, 2012).

Conventionally, street entrepreneurs were either seen as a residue from a premodern era that is gradually disappearing, or an endeavor into which marginalized populations are driven out of necessity in the absence of alternative ways of securing a livelihood. In recent years, however, participation in street entrepreneurship has been re-read either as a rational economic choice or as conducted for cultural reasons (Williams \& Gurtoo, 2012). Nowadays street entrepreneurship provides a new lens through which to engage with a longstanding focus on small-business proprietorship (Doody, Chen \& Goldstein, 2016).

Regarding the scope of financial ambition, given the small scale of its establishments, street entrepreneurs offers the possibility that an ordinary worker could quit his or her job and start a business with family members. They are relatively free to make day-to-day operating decisions and coordinate the development of their business. They tend to relate to innovative technologies, practices, and forms of service provision as end users rather than developers (Doody, Chen \& Goldstein, 2016). 
Street entrepreneurs despite being innovators, risk-takers, and business creators (Doody, Chen \& Goldstein, 2016) face some challenges. For example, they now tend in terms of specialization and marketing, since these businesses have to play up aspects that are increasingly important in terms of competing with competitors. Aspects as the artisanal, craft, and local nature of food has become essential to the success of many of these ventures, which can no longer compete only based on price and therefore must provide value in other ways (Doody, Chen \& Goldstein, 2016; Johnston, 2008).

It is in this context that a better understanding of how street entrepreneurs discover and exploit opportunities in the low-tech food industry becomes important. Understanding how they can be innovative, in the Schumpeterian sense, especially in economic and social crisis, helps to realize possibilities for adding value and minimizing the risks involved in the activity.

\section{Entrepreneur motivation}

The main difference between street vendors and other entrepreneurs lies in their necessity and opportunity orientations. Opportunity-based entrepreneurs are those who choose to start their own venture because they see a business opportunity to which they can respond better than anyone else does. A typical street vendor is a necessity-based entrepreneur who starts a business because other employment options are either unavailable or unsatisfactory (Reynolds et al., 2002). Entrepreneurs coming from unemployment are more likely to start new companies for necessity reasons rather than for opportunity reasons (Morelix, Fairlie \& \& Tareque, 2017). This underlying difference between these two groups leads to their different behaviors and attitudes. In fact, the entrepreneur's motivation can influence if the business will be innovative or not, even though motivation may change over time, varying from independence to profit purposes.

In this sense, there is an extensive literature regarding formation processes of entrepreneurial intention or motivation (Krueger Jr. et al., 2000). The perspective based on entrepreneurs' motivation, adopted by GEM research, considers as "entrepreneurs by necessity" those who initiate an autonomous enterprise for not having better job options; they need to open a business in order to generate income for themselves and their families. In contrast, "entrepreneurs by opportunity" would be those who, even though with other alternatives of employment and income, identified a chance of attractive business and decided to start the venture (GEM, 2013; 2014).

In addition to motivation, another important category that needs consideration, in the analysis of entrepreneurship on street ventures family firms, is how knowledge is diffused, since every technology/knowledge has its own diffusion curve, starting with someone's invention/development and spreading among competitors throughout the market. As knowledge diffuses, the market becomes more competitive, directly affecting supply and demand equilibrium, as well as profitability and market share.

\section{Knowledge creation and diffusion}

Knowledge relates to innovations, and innovative entrepreneurship is considered an important pillar for economic development (Block et al., 2017; Kuratko, 2011). One of the possibilities for companies to innovate is by engaging in research and development 
activities. Another possibility, alternatively, occurs by trying to imitate other firms' (König et al., 2016). The second option is much more likely to occur in family firms, given its nature. However, when knowledge diffusion is addressed, it is necessary to remember that, before its diffusion, knowledge needs to be developed/created.

In this sense, studies about service innovation have argued that the innovation process is more informal and ad hoc than innovation activities in the manufacturing sector (e.g. Sundbo, 1997), as in the case of the street entrepreneur. Den Hertog (2000) suggests four dimensions of novelty on service innovation: a) Service concept: a service new to its particular market (new value proposition); b) Client interface: changes in the way clients are involved in service design; c) Service delivery system: changes in the way which service worker performs his jobs delivering critical services; d) Technology: great efficiency obtained though information technology into process and delivery innovation.

\section{Relation between motivation, knowledge diffusion and entrepreneurship}

It is possible to observe relations between characteristics of entrepreneurs, according to their schools (Neoclassical, Austrian and Schumpeterian), different stages of technology diffusion and, finally, their motivations. As shown in Fig. 1, a three-category classification is proposed:

The Entrepreneur Type A is externally opportunity-driven; he/she foresees a market opportunity and develops an innovative solution, using at least one of those four aspects pointed by Den Hertog (2000). Type A is also internally driven by a will of autonomy and challenge, and trusts his/her own capacity to accomplish the endeavor proposed. Through the schools' classification point of view, this is the Schumpeterian Entrepreneur, that is innovative-destructive. Entrepreneurs type A compose the "Innovation group".

The Entrepreneur Type B does not have a market to innovate, once there is not a disruptive innovation in his/her proposal. They are categorized as part of the Austrian School. The market is already minimally tested, however it is not yet highly occupied, it is easy to find information and the necessary knowledge to start the business; suppliers

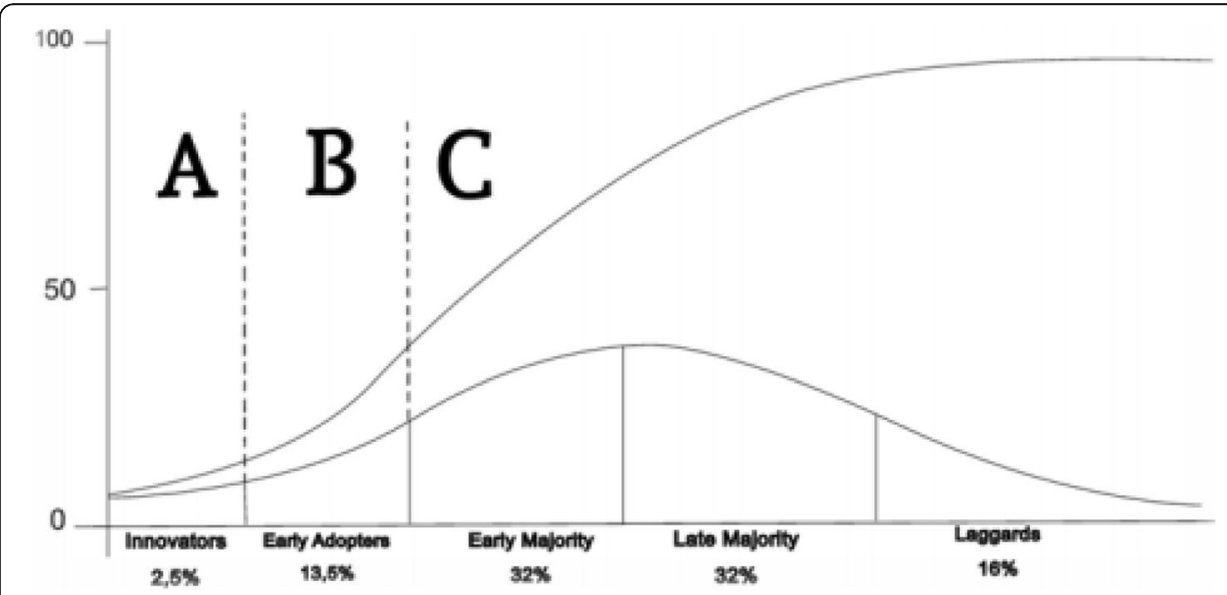

Fig. 1 Knowledge Diffusion. Source: Authors adapted from Ryan and Gross (1943) 
help with information and support transferring knowledge to new entrants once it is strategically for them. Type B is internally driven by a will of autonomy and challenge, and trusts his/her own capacity to accomplish the endeavor proposed. Entrepreneurs Type B are part of the "Transition Group".

Finally, the Entrepreneur Type $\mathrm{C}$ is a necessity-driven entrepreneur, normally in times of economic downturn. When job opportunities diminish and unemployment sky rocks, finally it is time to become an entrepreneur. The intended market is researched, understood and unveiled. Successful trajectories are seen and they serve as inspiration, and these entrepreneurs decide to endeavor due to the sectors' low risk (once the model has been already tested) and some incremental improvements are made on organizational processes or on the products. They are categorized as neoclassical entrepreneurs, according to the entrepreneur schools model. Entrepreneurs Type $\mathrm{C}$ are part of the "Commoditization Group".

There is a possible climb at the "Entrepreneur Leader", however, Shi and Dana (2013) proposes that market orientation has been assumed conducive to entrepreneurship and innovation. The hypothesis proposed here is that as the market becomes more mature, and its knowledge diffusion spreads, new venturing entrepreneurs become less "Schumpeterian entrepreneurs" and more "Neoclassical entrepreneurs". Even though there are novelties on their products or processes, there is almost no space for innovation at these already built, institutionalized, regulated and known product and market.

Therefore, as shown in Fig. 1, there are: a) Innovators: the Schumpeterian entrepreneurs; b) Early Adopters: related to the Austrian School; c) Early Majority, Late Majority, Laggards: related to Neoclassical Entrepreneurs. The more diffused a technology is, less innovative/Schumpeterian the entrepreneurs' family firms are and, therefore, more rapidly the market necessity will be fulfilled. An extremely known theory will be, therefore, suited: when offer surplus demand, prices fall. Moreover, probably the case of food trucks is adequate to analyze this proposition, representing street entrepreneurs, i.e., low-tech enterprises.

\section{Food trucks}

The Food and Agriculture Organization (FAO) defines street foods as ready-to-eat foods and beverages that are prepared and sold by vendors or hawkers, especially in the street and other similar places (FAO, 2016). Food trucks are part of the broader category "street vendors" (Rishi, 2013), in which one of the important aspects is its ability to generate entrepreneurial work opportunities (Alfiero et al., 2017). An example is that the street entrepreneur movement of food trucks in the United States has a strong relationship with the crisis experienced by the country. It strongly correlates with the increase in unemployment that led many chefs from restaurants to look for more viable alternatives than opening a restaurant (Hawk, 2013; Kregor, 2015).

Food trucks family firms are responsible for the modernization of street entrepreneur, regards to the form of production, sales and communication with customers (Rishi, 2013). They have become an urban cultural phenomenon, since the demand for street vendors has sharply increased among urban populations (Shin, Kim \& Severt, 2018). They are adapted trucks with kitchen equipment such as refrigerator, cookers and counters (Vedana et al., 2015), selling more sophisticated food (called "gourmet"), that differs from those sold traditionally on the street, almost 
approaching food offered in restaurants (Rishi, 2013). Often, their owners are highly trained chefs and, sometimes, owners of well-known restaurants (Mclaughlin, 2009). They do not have a fixed location and use communication and geolocation technologies to inform consumers about their location (Kregor, 2015). Undoubtedly, the entrance of food trucks family firms was responsible for the modernization of street food (Vedana et al., 2015). As a result, the first entrants made an incremental innovation to expand that kind of business, which resulted in a greater range of the target audience and differentiation in the customer base.

The failure of traditional street vendors is a striking contrast to the successful efforts of these entrepreneurs (Martin, 2014). In fact, there was success and a strong expansion of food trucks (Alfiero, et al., 2017; Hawk, 2013; Kregor, 2015; Williams, 2012). An inquiry on Google Trends (2018) search by the theme food truck around the globe and, in Brazil, it shows that we are facing a contemporary phenomenon that has attracted interest over the years. In fact, a survey conducted by National Restaurant Association (2011) found that food trucks are one of the most evident trends in the restaurant industry at the time. The same survey indicated that consumers show growing interest in mobile food services, and six out of ten consumers would visit a food truck if their favorite restaurant offered one. In addition, according to Rishi (2013), street sales drive the economy substantially, affecting the local economy.

Possibly inspired by these initiatives from abroad, in Brazilian cities, street entrepreneurs focused on gourmet food trucks are also spreading (Ross et al., 2015). Within the expansion of gastronomy on the national scene, the street food appreciation went beyond the traditional concept of cheap food for low class people and has become a cultural element, attracting people from every stratum. In addition, their business model bases on events designed to attract people with greater purchasing power (Dorigon, Bonamigo and Malheiros, 2014).

\section{Research methodology}

This research bases on a qualitative approach, since this is a nascent area of study and interest in society. A search for "food truck" in Google Trends demonstrates that the subject aroused interest practically null until the beginning of 2010, considering all the searches on the subject in the internet worldwide. It is available in Fig. 2:

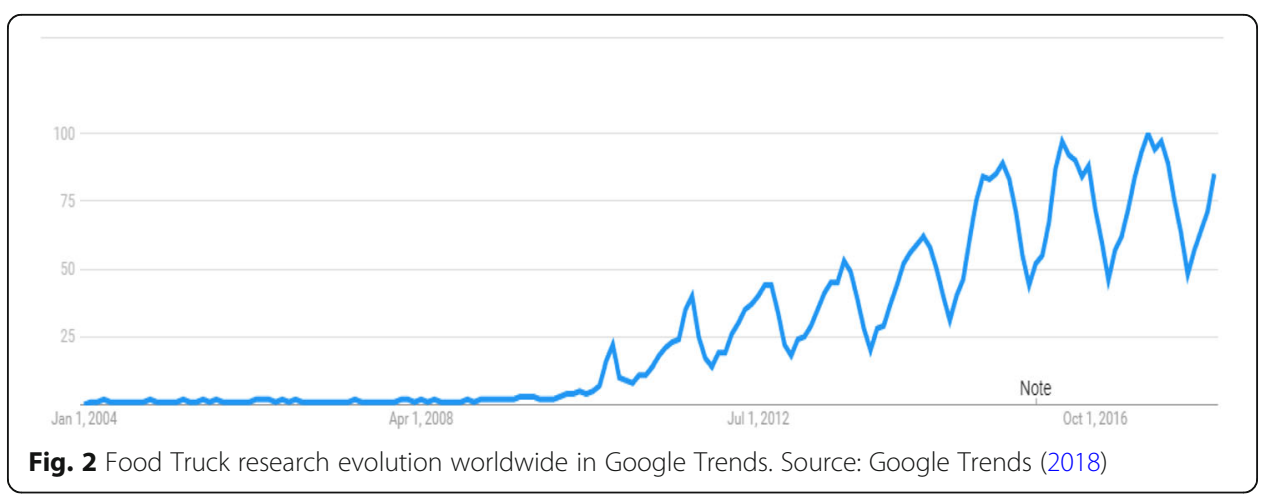


In the academic field, a search for "Food Truck" on Scopus, database with the more comprehensive coverage of the latest literature (Harzing and Alakangas, 2016), without any restriction of period, language, subject area or document type, resulted in only 57 documents, none of them examining the same issue.

Broadening, the search for the term "food AND truck" found 770 documents; however, most articles deal with other topics, not related to this type of business. Moreover, the search for "food AND truck AND innov"*" resulted in only 20 documents, of which only six are published in peer review journals in Business, Management \& Accounting and Social Sciences. The search for the terms "food AND truck AND entrepreneur" resulted in only five documents, and only two of them are published in peer review journals. Finally, the search for the terms "food AND truck AND entrepreneur AND innov " did not match the results. This indicates it is an emerging theme. Alfiero et al., (2017), Ross et al. (2015) and Shin, Kim\& Severt (2018) confirm this, since they also identified that food truck is an emerging research issue. Therefore, this is an exploratory investigation.

Case study is the research strategy chosen for the investigation. This strategy is indicated in situations when "how" or "why" questions are proposed, the researcher has little or no control over behavioral events, and the focus of study is a contemporary phenomenon (Yin, 2017).

\section{Data collection}

The process of data collection followed the Case Study Protocol proposed by Yin (2017). It consists in an exposure of the research objective, cases selection criteria, approach to organizations, preparation for data collection, conduct of interview and observation, and return of the results to participants.

The data collection was carried during June and July 2017, through participant observation and in-depth interviews, due to the exploratory nature of the research. In this technique, the researcher observes participants' verbal and non-verbal behavior, their environment, makes field notes, audio and video tapes, among others (Moreira, 2004).

As proposes Yin (2017), direct observations, i.e., field observations with diaries, are relevant since a case study will likely take place in the real-world setting of the case. Assuming that the phenomena of interest have not been purely historical, some relevant social or environmental conditions will be available for observation. It also provides additional information about the topic being studied.

First, a participant observation period in loco of the enterprises operations took place, with emphasis on analysis of two food parks, i.e., specific events that bring together various food trucks, in addition to other places where food trucks park in public places. In this phase, it was analyzed the operation of 44 food trucks. Direct observation and informal interviewing have been used throughout this stage.

The cases selection that aim to develop theory is based on theoretical sampling. The theoretical sampling is characterized by the choice based on the pertinence of the cases in answering the research problem theory (Eisenhardt, 1989; Yin, 2017) and in the relevance of understanding the logic or the existing relationship between the theoretical constructs to be investigated (Eisenhardt \& Graebner, 2007). The cases selection also need to be based on sufficient access to data 
whether to interview people, to review documents, or make field observations (Yin, 2017).

Angrosino (2009) proposes that, in these investigations, the sampling technique is more focused in the place for the observation or in the choice of fields and institutions than in selection of people. The city chosen to conduct the research, Porto Alegre, is a relevant capital in Brazil, considered a cultural capital, in which innovative businesses usually arise. The choice of the analyzed events occurred because they were major events in the city, with the greatest number of food trucks present. The single sites chosen to observe sought to include in the research the food trucks that were not in these two major events. It is estimated that this investigation could reach about $85 \%$ of the food trucks that were operating in the city at the data collection moment.

After this initial phase, in-depth interviews were conducted with 11 owners of food trucks family firms. All 44 food trucks present in the food parks analyzed were invited to participate in the survey, in addition to informal conversations that were held with them. The interviews were conducted with a semi-structured questionnaire, with open-ended questions. The questionnaire was developed from information collected in the observation stage and based on prior literature. It is available on Appendix. In addition to a pre-test with three food trucks, the questionnaire was also reviewed by two experts, university professors with more than 20 years of experience in the field of innovation.

The criterion that determined the choice of the interviewees was: a) to be a food truck family firm; b) to have availability for an in-depth interview. Regarding the number of interviews, it is important to point out that the quality of the responses obtained from respondents, not the number of interviews, is the great challenge. In this research, after conducting 11 interviews, it was noticeable that information from respondents was repeating. It was achieved, at this point, the answers redundancy stage, and it is defined by the closure of data collection.

In total, we obtained $5 \mathrm{~h}$ and $20 \mathrm{~min}$ of interviews. The conversations were recorded in digital media and later transcribed to enable content analysis. The names of the companies interviewed are confidential regarding ethical issues. Seeking to establish the construct validity and reliability of the evidence, it was adopted some principles proposed by Yin (2017) regarding data collection: use multiple sources of evidence (observation and interviews) and create a case study database (Nvivo 11 software).

\section{Data analysis}

The gathered data was analyzed by content analysis, with joint participation in all processes of three researchers, who coded and enhanced the analysis together. Considering the importance of drawing meaning from data, Miles and Huberman (1994) provide a list of tools for coding techniques and systematical schemes, in order to preserve part of data richness, to create categories and to recognize relation among those categories. They were observed in this research.

In this sense, the main steps used in the data analysis were: 1) consolidation of data (selection, transformation, codification and aggregation of raw data); 2) presentation of data (data organization and display); and 3) elaboration of conclusions (identification of relation among categories). In this sense, the content analysis of both phases was 
carried out with the help of Nvivo 11 software, which supports qualitative and mixed research, helping to organize, analyze and find patterns of responses in qualitative data.

The codification and the patterns are important decisions (Miles \& Huberman, 1994). As proposes Eisenhardt (1989), dimensions can be suggested by the research problem or by existing literature. Also, the researcher can choose some dimensions that may be relevant to analysis. The theoretical framework served as a guideline for the data collection, aiding the coding process. The data was categorized in the broad categories: food truck profile and demographics, entrepreneur's motivation, mode of operation of the food trucks, innovation, and knowledge and knowledge diffusion.

\section{Results and discussion}

The 11 food trucks surveyed in this study have, on average, 12 months of operation. In general, these businesses have two partners actively working and almost unanimously declared to have higher education or graduate. All interviewees have only one food truck, although some have other businesses, such as restaurants, bakery and food factory. Table 1 presents some data from the interviewed food trucks:

When seeking the explanations for participation in street entrepreneurship activities (Williams \& Gurtoo, 2012), among the main reasons given for the choice of having a food truck, it was identified the personal interest to work with food, the perception that this market is growing and allows profit, the desire of having their own business, the low investment compared to opening a physical enterprise, mobility to go to the client's meeting and schedule flexibility.

For example, regarding motivation, Food Truck owner 2 says, "My partner and I had a shoe store in the metropolitan area of Porto Alegre and with the low (customer) movement we were looking for new opportunities for greater profit". Food Truck 6 owner says, "We realized that the food truck market has been growing. We both have experience in the kitchen, he worked in the United States making hamburger and I worked in a Japanese restaurant". The owner of Food Truck 8, who already has a restaurant, explained that his main motivation was "to take advantage of the wave of

Table 1 Interview's summary

\begin{tabular}{llll}
\hline Food Truck & Interviewee & Duration & Business Time \\
\hline 1 & Owner & $31 \mathrm{~min}$ & 11 months \\
2 & Owner & $21 \mathrm{~min}$ & 1 year \\
3 & Owner & $27 \mathrm{~min}$ & 2 years \\
4 & Owner & $17 \mathrm{~min}$ & 9 months \\
5 & Owner & $26 \mathrm{~min}$ & 1 year and 8 months \\
6 & Owner & $46 \mathrm{~min}$ & 1 year \\
7 & Owner & $23 \mathrm{~min}$ & 11 months \\
8 & Owner & $29 \mathrm{~min}$ & 1 year and 6 months \\
9 & Owner & $44 \mathrm{~min}$ & 11 months \\
10 & Owner & $32 \mathrm{~min}$ & 1 year and 1 months \\
11 & Owner & $24 \mathrm{~min}$ & 8 months \\
\hline
\end{tabular}


food trucks, to use this movement as a kind of advertisement for my restaurant, once I already have the structure that facilitates the work here". In addition, Food Truck 5 owner says that "the great difficulty I faced in my other food endeavors was the challenge of taking the customer to our establishment, here [in food trucks] we go to the place the customer is".

The word mobility was quoted practically by all the interviewees when they were asked why they chose a street entrepreneurship. Some answers explained in more detail: "I was 'locked' in the office for many years and I like being on the street, the food truck gave me the possibility of mobility that I was looking for" (FOOD TRUCK 1 OWNER); "It's more practical, because we can go where customers are" (FOOD TRUCK 2 OWNER); "I wanted mobility, not getting stuck, and going to the customer (FOOD TRUCK 5 OWNER);" "For mobility, and flexibility of schedules, that counted a lot "(FOOD TRUCK 11 OWNER).

The lower cost compared to the physical enterprise was also pointed out by respondents, specifically citing cost reducing on rent and maintenance of workers in low demand times. The owner of Food Truck 2 says that "The cost to make a food truck is less than to open a physical store, also you do not need to pay rent". The owner of Food Truck 11 says that for him it is an "alternative rather than opening a restaurant". The owner of Food Truck 6 explains that cost and mobility questions were determinant for their decision: "lower cost than opening a fixed enterprise, and does not have the cost of staff, rent". The possibility of mobility and efforts to reduce costs indicated in the interviews allow to infer that, in the food truck option, there is less need for knowledge compared to the physical development, because in the second option there is a need to assess the feasibility of the product offered for region where the enterprise is established.

Interestingly, as some of the above quotations demonstrate, among the 11 food trucks, in four of those the owners already run their own business: three of them in the food area, one of them with international experience and another case of a restaurant owner for 11 years (which saw the food truck as a business opportunity, a way of "advertising" his restaurant). Another food truck owner works with food for over 20 years. He was a chef, and always had projects in the food industry. Among people with this profile, the main reason to build an entrepreneurship business on the street is the perception of profitability. For example, the owner of Food Truck 5 explains that:

"I've always enjoyed cooking; I have been working with food for more than 20 years. I had a bakery in the 1990's, took a chef's course, worked in restaurants, and went out on a routine issue that bothered me. I lived in Los Angeles for 2 years and followed the appearance of Food Trucks in 1997, as well as in other trips I made. After 2012, already in Brazil, I decided to return to the food sector and started to market pizzas. At this time, I went to a food event, which aroused my attention to the food trucks, this business was almost nonexistent here in the south of Brazil yet, and so I did a market research and thought it would be a profitable business. Therefore, I decided to make a hamburger food truck because I have experience in this type of cuisine and saw a good profit opportunity" (FOOD TRUCK 5 OWNER). 
These entrepreneurs can be classified as opportunity-based entrepreneurs (GEM, 2013; 2014; Reynolds et al., 2002) since they saw a business opportunity motivated by profit purpose. As proposes (Doody, Chen \& Goldstein, 2016) these food trucks owners seek a new lens to engage with a longstanding focus on small-business proprietorship (Doody, Chen \& Goldstein, 2016). Considering the classification of GEM (2015; 2013; 2014), it is possible to consider most of these activities as entrepreneurs in early stage (new, because they are already generating income to the owners) and with influences of education and training of owners in business.

Those entrepreneurs, who mentioned the recognition of a business opportunity in food trucks, conducted market research before opening their business. In some cases, the research took up to one year of analysis using external consultants, observing food truck events and monitoring their movement in other states of Brazil, as well as researching on the internet for inspirational insights on Brazilian trucks and especially outside the country where the activity is more consolidated.

In this sense, Food Truck 1 owners reported that they conducted market research for 6 months before starting food truck activities. They said, that in this period, "We took courses at Sebrae (a Brazilian institution that offers small business consulting services), used the internet to research business options, evaluate other food trucks in São Paulo (financial capital of the country), because at that time still there were not many food trucks in operation here in the city, it was all unknown and we needed to understand what was happening in other markets. We were trying to understand everything that was possible about this market, management errors, news, everything [...]".Food Truck 2 owner said that "We came up with ideas that we saw about food trucks operation outside Brazil". The owner of Food Truck 3 reports that "We researched in websites, at the time there was very few [food truck] in São Paulo, here in Porto Alegre there were only two food trucks operating. We went to São Paulo to ask for information and together we researched in internet about food trucks outside Brazil that were successful". The owner of Food Truck 4 reports that "I searched everywhere you can imagine, especially in other states of Brazil". Food Truck 5 owner says that "I researched about food trucks in the United States, taking advantage of the learning of the time that I worked there and completing with new researches via internet". Food Truck 10 owner said that "We conduct our own research in several places such as websites and fairs in São Paulo, we did gastronomy courses and then we started the business plan".

From these findings it is possible to identify that, in the absence of knowledge or ventures of this type in the city or region analyzed, a significant part of the entrepreneurs sought their knowledge in other Brazilian states and/or in other countries. In these places they investigated, the market already showed a higher level of maturity according to the interviewees' speech, which sought to understand, in addition to opportunities, the points that led to the failure of businesses of the same type.

However, there are also indications, in lower degree, of entrepreneurs motivated by necessity. For example, one of the enterprises interviewed stated that he was fired from his job and decided to start a food truck as an alternative of income: 
I have always enjoyed cooking, I made recipes on weekends at home, but I had never worked with it. I wanted to have my own business, but I worked in the trade as an employee. At one point, I was fired and, in an impulse, I decided to begin working with the food truck, because before leaving the job I thought about it. (FOOD TRUCK 4 OWNER).

As it is possible to see in his speech, he had no previous experience with food or street entrepreneur. In this case, the entrepreneur behavior is not related with previous experience, which differs from Ozaralli \& Rivenburgh's (2016) proposition. Therefore, he can be classified as a typical street vendor, i.e., a necessity-based entrepreneur (GEM, 2013; 2014) since he started the business because employment options were unavailable or unsatisfactory (Reynolds et al., 2002). This finding is aligned with the proposition of Morelix, Fairlie \& Tareque (2017) that entrepreneurs coming from unemployment are more likely to start new companies for necessity reasons rather than for opportunity reasons.

In any case, it is possible to perceive elements pointed out by Khefacha \& Belkacem (2015), Kuratko (2011) and Ozaralli \& Rivenburgh (2016): demographic, competencies, networks, perception factors (such as passion for food), education, economic and political climate. However, none of them indicated they were seeking to be free to coordinate the development of a business, as proposed by (Doody, Chen \& Goldstein, 2016).

None of them reported the use of new technologies in its production process. In fact, due to its low technological nature, food trucks rely mainly on people work. As Brouthers and Brouthers (2003) point, once services tend to be people intensive, the result is that the competitive advantage tends to be derived from idiosyncratic assets. An example is investments in training and knowledge. Undoubtedly, as proposed by Brouthers and Brouthers (2003), once services are people intensive, they tend to be inseparable and perishable because production and consumption are normally linked geographically, and the service firm needs to be present at the time of production and use, and services cannot be inventoried. Most entrepreneurs reported using existing technologies in their communication processes. The eleven food trucks reported making use of social media to inform their location to customers and publicize the events. These finding is related to the proposition of Doody, Chen \& Goldstein (2016) that these entrepreneurs tend to relate to innovative technologies and forms of service provision as end users rather than developers.

Exploring characteristics that differentiate a food truck from a street entrepreneurship and situating it as a niche market, the respondents cited: a) food trucks generally offer products with better quality, which adds more value compared with regular street food; b) food trucks have more elaborated appearance; c) there are several forms of payment available; d) investment is higher than other street endeavors; e) stronger regulation leads to a greater hygiene and quality; f) the mobility and possibility to use refrigerators and freezers also have a great influence.

For example, food truck owners made the following statements: "Of course, there is the financial difference of those who can afford to build a car because the investment is high. It also has a more hygienic and clean structure, but we, for example, came from the tent." (FOOD TRUCK 1). "The food is more elaborated." (FOOD TRUCK 2). "Food truck is distinguished by the structure, has refrigerator, freezer and others that your 
tent has not, besides mobility, once we have wheels." (FOOD TRUCK 3). "Food trucks differentiate themselves by the whim, car's appearance and the form of payment." (FOOD TRUCK 4). "The normal street entrepreneur has a product that almost everyone has the same by a cheaper price. Food truck has the concept of serving quality food on the street, it is a differentiated product on the street." (FOOD TRUCK 5). "It is different because the concept of food truck is an easily accessible gourmet food, so the food truck adds value to food compared to the common street entrepreneur." (FOOD TRUCK 6). "The street projects in general are very retrograde; in this sense, food trucks are super innovative in comparison with others." (FOOD TRUCK 11).

They best sales performance happens at events in public spaces, together with other activities such as fairs, music festivals and other trucks, than in isolated spots. Their target consumer are middle-class young people who participate in these street events and are capable and willing to pay more for "gourmet" food, i.e., higher quality food than those usually sold on the street, very similar to those sold in restaurants, in terms of quality and variety.

As an example, follows the speech of some food trucks owners: "Before, there was a boom in shopping malls. Now people are coming out more, turning more to their neighborhoods, something that was once gone and is now coming back" (FOOD TRUCK 1). "Our audience has been the event staff, willing to pay more for quality product" (FOOD TRUCK 6). Both food truck owners 9 and 10 reinforced many times that their larger public has been young people who attend these street events. In addition, "I thought our audience would initially be anywhere, but now we see events as a great opportunity" (FOOD TRUCK 11).

Concerning the regulation, all the respondents said it is important, though opinions differ when they answered if it helps or restricts their businesses. Those who see the legislation as favorable mentioned the need of caring with food safety. The biggest concern among the critics regards to the highly bureaucratized processes within all areas in which there is government involvement. One respondent reported that, at the beginning, the lack of regulation was a great barrier during the business opening process. Another interviewee explained that they are prohibited to work on street regularly, because of the absence of specific law. Therefore, their options are to take part on an event, or work in partnership with a regular shop, parking in front of it. However, the same respondent affirmed that events bring their biggest sales.

Since entrepreneurs are recognized for their posture of innovativeness and pro-active pioneering of new markets (Zhang, Groen \& Belousova, 2018), to understand how entrepreneurs in low-tech food companies in emerging countries enhance innovation performance (Alfiero, et al., 2017; Zhang, Chen \& Kane, 2018), it is important to clarify what these entrepreneurs understand as innovation. The answers were multiple, and mostly used the expressions creativity, novelty and "small details". When asked to explain further, they presented examples related to changes in menus and recipes in food as innovation. Excerpts from the answers are available in Table 2.

Based on their understanding of what is innovation, the entrepreneurs answered if they think the offered product is new or not, and whether they consider if the product has some different characteristics. Most answered that their product are not new, and only a small group believes to offer new products, justifying the novelty as linked to the fact that the product is handmade and has a different recipe. 
Table 2 Concept and self-perception of innovation by the interviewees

Food Truck What do you understand as innovation? Is your food truck innovative?

1 "Innovation is creativity and detail, who is creative remains in the business. However, I do not think my food truck is innovative at all, because the hot dog carts have been around for a long time, and now they have got a little more style and personalization. We are entrepreneurs, we came when the trend was already happening, and we were behind. We studied a lot food trucks stabilized in São Paulo and abroad, we calculated values, we set up the structure. There was already a food truck with the same style of product in the region of São Paulo, and we inspired in it, but we brought the novelty here."

"Innovation is bringing something new to the market that adds quality to customer and society. I believe we are innovative because we are the only food truck that has sliced pizza in the region, also because I offer a handmade and sliced product, not yet on the market".

"Innovation is to bring something new to the market that adds quality to the customer and society. At first, I was innovative because there was no one in Brazil with the same product, now there are other trucks on the market, even because the coffee, our base product, is not innovative. However, I am innovative because at first, there was no food truck like this, but our differential is still that we have refrigeration. I think we have to innovate again. But inside the country certainly food truck is still innovation and novelty."

"Innovation for me is to perceive the opportunity. However, nothing is created; everything is transformed, because innovation is very broad. Brownie and brigadeiro [brigadeiro is a Brazilian typical sweet] already existed, we did not create anything new, our innovation is in the form of presenting. In addition, we created our cart, developed the model, and the project. I am innovative because of how we present our product to the customer."

"It's all that you do that others are not doing yet, and that, for example, innovates your menu, your food, your presentation. We are innovative because we offer the product in a different way and our menu is our own recipe"

"It is not inventing the wheel, but to use a vision with alternatives that change what is common. We are innovating without innovation. For example, we do not do anything different, but we work with quality products in a different way, so you do not need to reinvent the wheel. Within the ordinary, you can stand out with quality. That is why our enterprise is different, for the quality. Our burger is different. I'm innovative for the quality of the product offered, by calling the customer by name, explaining, talking."

7 "Innovation for me is to turn something old into something new. We are innovative because we are a kitchen on wheels, and we can take food anywhere."

8 "Everything that is new, that brings benefit to the customer, or to someone who is willing to develop their business, is an innovation. The trucks themselves are innovation, since sales decreased with the crisis. Going to the streets is a way to meet the customer and solve this problem of sales decrease. The food truck has always existed, but it is innovative for us by bringing a higher quality food and being more concerned with the appearance of food. We are innovative, because in terms of pancake, we are unique, by chasing the customers and willing to be in different places".

9 "To bring novelty and quality to the market, something with a differential, which may be in the product, or in the way you present the product. There are some aspects in which we are innovative within the food market, the way we prepare the pizza, the way we conduct the social media."

"Innovation can be a lot of things. For me, food trucks were already innovative, but now they are already popularized. We can consider innovation in Porto Alegre, in our city, but not in São Paulo, because there they are so ahead of us. Innovation within the food truck and new things is not to stay in the same, to promote new things. In our case, we are innovative. Food recipes is where we are most innovative."

11 "I consider innovation as adapting to the needs of customers, being able to sell and please the customer. I consider myself one of the pioneers in food truck in the city. When I opened [the enterprise] I was one of the first to open here. I consider myself innovative because it is risky to be the first in the city"

Similarly, when asked if the product they sell is unique, almost everyone responded affirmatively, still under the justification of recipe. Only one of the owners replied that, at first, his product was unique because it was the only one made that way in Brazil, but it was widespread and no longer represents a unique product. 
About their food truck business being innovative, most answers were affirmative and, again, justified by differences in menu and product presentation. This indicates a predominantly divergent understanding of "innovation" proposed by Schumpeter (1961), the main assumption underlying this research. For the public studied in this research, innovating can be simply having a "different recipe from others", "bringing something new" or "seeing what the market wants and what is not available". Such propositions are much more aligned with the concepts of Hawk (2013) and Kregor (2015), or essentially the search for viable and cost-effective economic alternatives, especially considering a crisis scenario, as can be found in GEM (2013; 2015). Nevertheless, as proposes Doody, Chen \& Goldstein (2016) and Johnston (2008) such characteristics refer to the communication of these products as artisanal and local, and it is essential to the success of these ventures.

Table 2 summarizes the most explanatory excerpts given by the respondents regarding the concept and self-perception of innovation by the interviewees:

When asked about how they update their information about food trucks business and market trends, some answers received were: "We look for updates with Sebrae (a Brazilian institution that offers small business consulting services), seek information with the Food Institute Trucks located in São Paulo on market trends, news, research about management errors in internet, and new possibilities of action, as well as looking for international trends on the internet" (FOOD TRUCK 1 OWNER); "We update our market knowledge mostly through the internet, television programs and business books" (FOOD TRUCK 3 OWNER); "We seek to update ourselves through Sebrae consultancies and researching about news on the internet. Travel abroad helps us to see what is happening outside [Brazil] and what we can bring here as a business (FOOD TRUCK 5 OWNER)".

Finally, when they were asked whether the products sold in the food truck had changed since the beginning of the business, the respondents responded positively. The main changes made in descending order were: adaptations/improvements in product offering and insertion of new products. The adaptations/improvements were originated in customer feedback and owner observations. The insertion of the new products was the result of consulting or research about trends in other Brazilian states or other countries.

As found by Alfiero et al. (2017), our results, from the observations and the interviews, indicate that, in the beginning, these food trucks represented an innovative service, mainly implemented by the gourmet tradition, and this lead them to be more competitive in the food sector. Wennekers and Thurik (1999) also have a good insert that fits well with this picture found through interviews, understanding that Schumpeterian entrepreneurs are found mostly in small firms. They own and direct independent firms that are innovative, creatively destroying existing market structures - and these Schumpeterians often develop into managerial business owners, but some may start again new ventures or firms.

The first entrants in the food truck market, especially those motivated by opportunities, can be classified as the German or Schumpeterian tradition, since, as proposes Wennekers and Thurik (1999) and Nooteboom (1993), these entrepreneurs create potential, instability and creative destruction. In the analyzed situations, they incorporated ideas that were already practiced in other countries and inserted as innovations in their 
regional context. Here is a theoretical contribution of this paper: the Schumpeterian innovation of these street entrepreneurs is highly geographically and contextual.

These street entrepreneurs of food trucks also introduced an incremental innovation to improve production processes and logistics in the food sector. One of the reasons for that may be related to the fact that the entry and enhancement of gourmet food in the street entrepreneurship brought a new consumption pattern. It added value to the street venture allowing its development and products sale at a higher price. Now acquires importance aesthetics, quality of the ingredients, refinement of the food offered, the cleanliness of the place and the consumption experience. This is relevant and cannot be forgotten, as it indicates the insertion of innovation at a certain level.

In this sense, these food trucks provided a product with higher value to the street entrepreneurs market and were able to identify where to reach the target consumer. This caused a significant impact on the pricing structure. As proposes, this was a new and creative solution for the crises faced by the country. These enterprises innovate, according to Den Hertog (2000), in three of the four dimensions of novelty on service innovation: service concept, client interface and service delivery.

In fact, these food trucks were actual Schumpeterian entrepreneurs when they first appeared. And it happened because there was a novelty on the street business that allowed reaching new audiences, creating and developing a market, where new features aggregated value to an archaic business. Since they created, changed and destructed constructively the street food market, they are Schumpeterian entrepreneurs as well. As proposes Shi and Dana (2013), our results indicate that market orientation is somehow related to entrepreneurship and innovation, but these family firms were less radical in their entrepreneurial processes and innovations.

In summary, an innovation process occurred in this particular market, based on very specific characteristics. The point is that innovation is highly linked with the fact that the environment itself is low-tech, that is, the available resources (invested) and the level of technology required for this type of innovation are compatible, as support Williams (2012) and McLaughlin (2009). In other words, probably this kind of venture, in another market, could not be seen as innovative, more so under the terms of Schumpeter, primarily focused on the fusion on the economic aspects of market relations.

Finally, one of the interviewed owners sees food truck as a good market opportunity nowadays and in the future. However, for her, it is an illusion to think that someone can earn a lot of money with a food truck. Doody, Chen \& Goldstein (2016) have also identified that this type of business allows for financial independence, although it rarely allows large-scale income. Besides that, the interviewee understands that, despite the high quality, it is just a niche of a street entrepreneurship. Also, she adds that, in her view, 2016 was the year of the culmination of profitability, because there was not as much dissemination of projects of this type as nowadays, and in that year major events were carried out. Only one of the respondents said that he, at first, thought the market was wider and now realizes that there is much competition. Another interviewee understands that this type of business is living its moment of maturation in the city and those who successfully pass through this time will remain in the long-term market. 
Therefore, based on observations and interviews, we understand that the diffusion of knowledge and expertise allowed the entry of new competitors in the market, just repeating the activity, without adding new value. So, the next entrants, even though having their own differentiations of brand, recipes, marketing strategies and so on, are mainly on the neoclassical paradigm, moving to this status also those who were once considered innovative.

In this way, it is understood that the "current" food truck market in that context is already on its early majority. The speech of one of the respondents supports this understanding: "We already had a $50 \%$ reduction on sales. It is clear that this crisis will separate those trucks that will be able to pass through and those who will not." It was used the term "current" food truck market, because it is understood that there is still a great opportunity for the street entrepreneurs to create new markets and their mobility characteristic is a great asset, through an innovation cycle.

Therefore, as previously said, their innovation is incremental, and improving a food truck production capacity seems one strategy for a market that is not innovative anymore, where a great flux of competitors with similar products will soon "kill themselves" on a price competition. One could contest that food trucks fulfil a niche between the regular street food entrepreneur and restaurants with better infrastructure and capacity to have more elaborated products. However, what once was a "blue ocean" due to its success, novelty, publicity and low entry barriers, will change, and those without strategies of differentiation/innovation will certainly perish.

Tiwari, Bhat \& Tikoria (2017) propose that creativity is also an antecedent that explains social entrepreneurial. Following this line, it is proposed that a new "wave" of creativity will be required for these ventures to succeed. If they cannot bring innovations to the market they are inserted, the great option that arises from these paper contributions is to change the context they are inserted. For example, food trucks are more widespread in Brazilian capitals, as Porto Alegre. Therefore, cities located in the interior of the State still represent potential places to enter as innovators. Even in the interviews, there was already an indication that the market was starting to have many players and entrepreneurs were starting to organize fairs in the interior of the State, where food trucks had this factor of novelty and innovation, no longer existent in the capital.

\section{Conclusions}

\section{Main findings}

This study addresses a gap pointed out in literary literature by Alfiero, et al. (2017), Farsi \& Toghraee (2014), Greeven \& van de Kaa (2013), Lefebvre et al. (2015) and Zhang, Groen \& Belousova (2018) when investigating innovation-related issues in small low-tech food enterprises, analyzing the case of Food Trucks in an emerging country as representatives of street entrepreneurs. While current studies understand that, due to their low technological standards, street entrepreneurs are not innovative (Reynolds et al., 2002; Bhola et al., 2006), the results of this investigation indicate differently. The street entrepreneurs' family firms analyzed can be Schumpeterian entrepreneurs, since 
they create innovations within the context of the market they are inserted, which gives them a competitive advantage in that specific market.

Our relevant theoretical contribution is to identify that the Schumpeterian innovation of these street entrepreneurs is highly geographic-contextual. Moreover, in this context, the dissemination of knowledge plays an important role, since the innovation verified is a dissemination of knowledge from other countries, especially from developed ones, or others States of the federation, applied to the regional context. Therefore, they revolutionize the market they are inserted. This finding aligns with Kuratko (2011) that understands knowledge as a power in economy. Hence, the ability to introduce knowledge into a market where does not exist results in a competitive advantage yet, occurred in food trucks as street entrepreneurs.

In times of crisis, in which employment is low and business failure increases in a country as Brazil, characterized by institutional uncertainty (Greeven \& van de Kaa, 2013), the finding that street entrepreneurs are highly geographic-contextual is relevant to literature and practice. In addition to corroborating other findings, it advances by identifying indications that in the moment these entrepreneurs apply the knowledge in their local context, they innovate and find a way to reduce the risk of business failure. This is important since, as proposed Zhang, Groen \& Belousova (2018), because of their innovative and experimental posture, these entrepreneurs may lead to more frequent failures.

If this finding is correct, this may be an important strategy for low tech entrepreneurs in emerging countries. Entrepreneurs could learn from other experience in relation to success and error and reframe strategies with Schumpeterian innovation and best success rates. This finding helps to addresses the gap pointed out by Companys \& McMullen (2007) to better understand the relationship between opportunity, innovation, performance and the strategies that are needed to discover and exploit new opportunities. It also addresses the gap identified by Zhang, Groen \& Belousova (2018) regarding innovation failure.

Figure 3 synthesizes the proposition of this study:

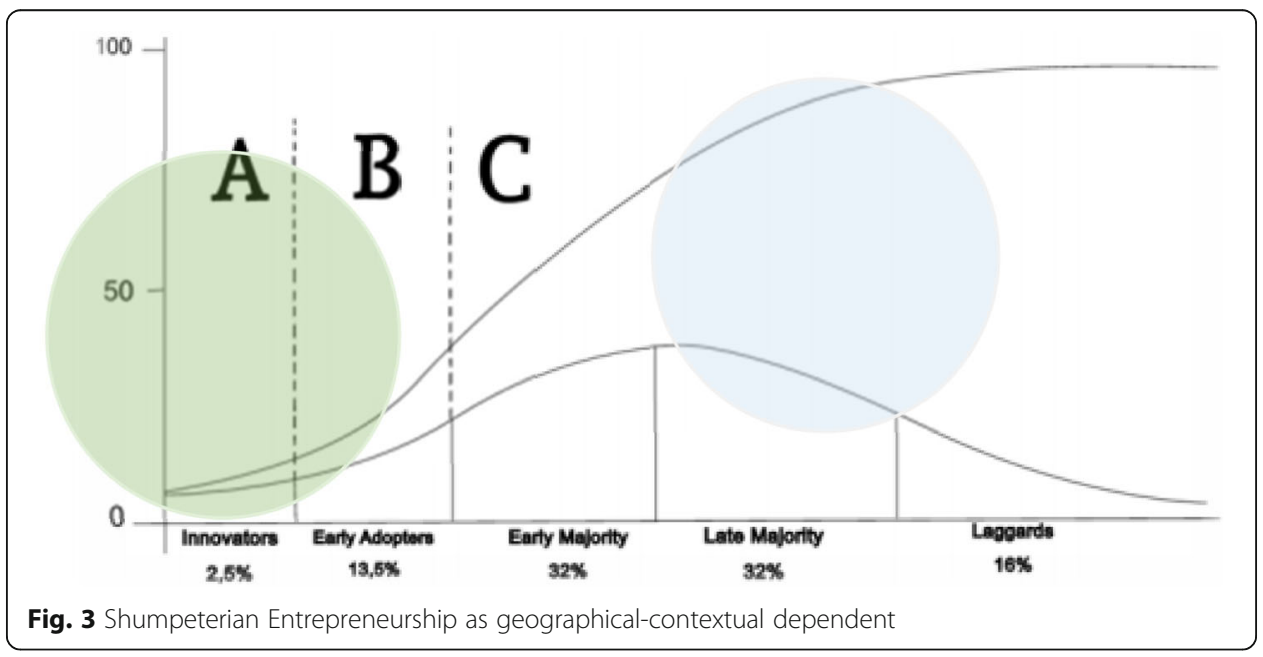


Context 1 represents other countries or other states of the federation that entered in this market for a longer time. Initially, the entrants were first movers, possibly opportunity-based motivated, but not exclusively, and they promoted a Shumpeterian innovation in the market. They faced a certain risk of business failure since they were first entrants/innovators (with some level of uncertainty). With the spread of this knowledge in the market and new entrants, they are no longer innovative and, therefore, lose their competitive advantage, changing their maturity stages as new entrants with the same knowledge/practices emerge. However, when this knowledge is disseminated and applied in context 2 as a novelty, disrupting the market, the condition becomes Schumpeterian entrepreneur again with the advantage of reducing the risks of business failure due to prior knowledge about the factors of success and failure. Although they are different contexts, they share many common characteristics.

This reinforces the geographic-contextual character of Schumpeterian innovation. To better clarify, an example follows about the case of an application or computer program, which uses platforms (technological infrastructure) to have greater capillarity. In this case, individuals in the United States and Brazil (on the limit) can benefit from an innovation. In the case of street entrepreneurs, which "necessarily" need physical presence for the service, the geographical-contextual character represents the difference in innovation related issues. This can be considered a positive factor somehow, once it allows the beginning of the innovative cycle in a context of changes.

A resulting managerial contribution is that small or medium low-tech businesses from emerging countries, which as a rule are not trendsetters, can seek knowledge about the economic activities of this type in enterprises that have stood out in other places. They can imitate by adjusting to the needs of the environment where they operate. At that location, they will act as Schumpeterian entrepreneurs by bringing an important innovation that will probably lead them to a competitive advantage, by being the first movers with lower risks. However, it must be clear that the condition of being a Schumpeterian entrepreneur is not permanent; innovation emerge, spread and alter market conditions.

\section{Limitations and future studies}

Although this study has brought some insights about street entrepreneurs, their motivations and the possibility of being Schumpeterian entrepreneurs capable of promoting differentiation and value in their businesses, there is a need to deepen the theme. Although this result cannot be extended to other emerging countries, it acquires relevance considering the representativeness of Brazil in this scenario, especially as it is the largest economy in Latin America. One limitation of this study is precisely the impossibility of generalizing the results, given the geographical and contextual limitation of the family firms group studied. Therefore, one of the suggestions for future studies is to carry out surveys with a larger number of street entrepreneurs in across different levels of analysis and geographic settings. Longitudinal studies with business that have been implemented based on dissemination of knowledge from other countries or regions may be interesting to assess in depth if the aspects identified in this study. 


\section{Appendix}

Table 3 Interview script

\section{Block 1 - Demographics}

1. Name

2. Age

3. Profession / academic background

4. Region of food truck action

5. Time of enterprise

6. Number of members

7. Number of employees

\section{Block 2 - Entering the business}

1. Do you have any other projects? Food trucks or others?

2. What were your motivations (antecedents) to open this venture?

Note: explore decision making, as it happened, which drivers were important.

3. Why the option for a street truck (food truck)?

4. What kind of information did you use to choose the food truck? Did you get any advice or something?

5. Do you think your product is new?

6. Do you think you have a new technology?

7. Do you understand your product as unique?

8. Do you have a clearly defined business model?

a) Is it clear where you operate? Where is it?

b) Do you have definitions or is it market-driven? Can you explain a little bit?

9. What are the influences of legal-institutional rules in your enterprise?

10. What led you to define your enterprise's type of product?

11. How are your processes of:

a) Production?

b) Commercialization?

c) Administrative?

d) Marketing?

12. What is your degree of knowledge $\left(\mathrm{k}^{*}\right)$ about the enterprise (previous items)?

13. Do you seek support in the market? (cost of governance / organization)

14. How do you see the market you are inserted?

a) What market is this? (Is it just food trucks or does he see himself as a street entrepreneur?)

\section{Block 3 - Innovation}

1. What do you mean by innovation?

2. How much do you think your venture is innovative?

a) Why?

b) Name innovative aspects of your venture.

3. How much - if it agrees and the answer is yes - is it important to be innovative?

4. Do you think street trades are innovative?

5. Do you think food trucks differ from other street trades?

6. Do you consider yourself innovative? Why?

7. In what ways is your business innovative? 
Acknowledgements

No acknowledgements.

Funding

Coordenação de Aperfeiçoamento de Pessoal de Nível Superior (CAPES).

\section{Availability of data and materials}

The datasets used and/or analysed during the current study are available from the corresponding author on reasonable request.

\section{Authors' contributions}

The study was carried out and discussed in depth by the three authors, under the supervision of a professor with more than 20 years of experience in the department of the Business School at Universidade Federal do Rio Grande do Sul. All authors read and approved the final manuscript.

\section{Competing interests}

The authors declare that they have no competing interests.

\section{Publisher's Note}

Springer Nature remains neutral with regard to jurisdictional claims in published maps and institutional affiliations.

Received: 21 March 2018 Accepted: 5 December 2018

Published online: 04 January 2019

\section{References}

Alfiero, S., Lo Giudice, A., \& Bonadonna, A. (2017). Street food and innovation: The food truck phenomenon. British Food Journal, 119(11), 2462-2476.

Angrosino, Michael, 2009. Etnografia e observação participante. Artmed: Porto Alegre. (Coleção pesquisa qualitativa).

Bhola, R., Verheul, I., Thurik, R. and Grilo, I., 2006. Explaining engagement levels of opportunity and necessity entrepreneurs. EIM bv, Zoetermeer. Retrieved from http://hdl.handle.net/1765/9705

Bhowmik, S.K., 2007. Street vending in urban India: The struggle for recognition. Street entrepreneurs: people, place and politics in local and global perspective, pp.89-123.

Block, J.H., Fisch, C.O. and Van Praag, M., 2017. The Schumpeterian entrepreneur: A review of the empirical evidence on the antecedents, behaviour and consequences of innovative entrepreneurship. Industry and Innovation, 24(1), pp.61-95.

Brouthers, K. D., \& Brouthers, L. E. (2003). Why service and manufacturing entry mode choices differ: The influence of transaction cost factors, risk and trust. Journal of management studies, 40(5), 1179-1204.

Companys, Y. E., \& McMullen, J. S. (2007). Strategic entrepreneurs at work: The nature, discovery, and exploitation of entrepreneurial opportunities. Small Business Economics, 28(4), 301-322.

Den Hertog, P. D. (2000). Knowledge-intensive business services as co-producers of innovation. International Journal of Innovation Management, 4(04), 491-528.

Doody, S., Chen, V. T., \& Goldstein, J. (2016). Varieties of entrepreneurial capitalism: The culture of entrepreneurship and structural inequalities of work and business creation. Sociology Compass, 10(10), 858-876.

Dorigon, C. B., Bonamigo, I. S., \& Malheiros, P. G. (2014). De estigma a valorização: panoramas da comida de rua a partir da cidade de Porto Alegre. In VII Encontro Nacional de Estudos do Consumo: Mercados contestados - As novas fronteiras da moral, da ética, da religião e da lei, 2014. Anais.. Rio de Janeiro: Pontifícia Universidade Católica do Rio de Janeiro, 2014. p. 1-10.

Eisenhardt, K. M. (1989). Building theories from case study research. Academy of Management Review, 14(4), 532-550.

Eisenhardt, K. M., \& Graebner, M. E. (2007). Theory building from cases: Opportunities and challenges. The Academy of Management Journal, 50(1), 25-32.

Farsi, J. Y., \& Toghraee, M. T. (2014). Identification the main challenges of small and medium sized enterprises in exploiting of innovative opportunities (case study: Iran SMEs). Journal of Global Entrepreneurship Research, 4(1), 4.

Food and Agriculture Organization of the United Nations [FAO], 2016. Street Foods. Retrieved from http://www.fao.org/fcit/ food-processing/street-foods/en/. Last access: July, 2018

Global Entrepreneurship Monitor [GEM], 2013. Empreendedorismo no Brasil: Relatório Executivo IBQP, SEBRAE, FGV.

Global Entrepreneurship Monitor [GEM], 2014. Empreendedorismo no Brasil: Relatório Executivo IBQP, SEBRAE, FGV.

Global Entrepreneurship Monitor [GEM], 2015. Empreendedorismo no Brasil: Relatório Executivo IBQP, SEBRAE, FGV.

Google Trends, 2018. Food Trucks. Google tool to analyze the evolution of the number of searches for a keyword over time. Retrieved from https://www.google.com.br/trends. Last access: January, 2018

Greeven, M. J., \& van de Kaa, G. (2013). Determinants of innovation in emerging economies: the case of Chinese entrepreneurial software firms. In Academy of Management Proceedings (Vol. 2013, No. 1, p. 17208). Briarcliff Manor, NY 10510: Academy of Management.

Gurtoo, A., \& Williams, C. C. (2009). Entrepreneurship and the informal sector: Some lessons from India. The International Journal of Entrepreneurship and Innovation, 10(1), 55-62.

Harzing, A. W., \& Alakangas, S. (2016). Google scholar, Scopus and the web of science: A longitudinal and cross-disciplinary comparison. Scientometrics, 106(2), 787-804.

Hawk, Z., 2013. Gourmet Food Trucks: An Ethnographic Examination Of Orlando's Food Truck Scene. University of Central Florida, Department of Anthropology, Electronic Theses and Dissertations. Retrieved from http://stars.library.ucf.edu/etd/ 2751. Last access: July, 2018

International Labour Organization [LO]. (2002). Decent work and the informal economy. Geneva: International Labor Office. 
International Labour Organization [ILO]. (2011). Statistical update on employment in the informal economy. Geneva: ILO Department of Statistics.

International Monetary Fund., 2017. Report for selected countries and subjects. World Economic Outlook Database. Johnston, J. (2008). The citizen-consumer hybrid: Ideological tensions and the case of whole foods market. Theory and Society, 37(3), 229-270.

Khefacha, I., \& Belkacem, L. (2015). Modeling entrepreneurial decision-making process using concepts from fuzzy set theory. Journal of Global Entrepreneurship Research, 5(1), 13.

König, M. D., Lorenz, J., \& Zilibotti, F. (2016). Innovation vs. imitation and the evolution of productivity distributions. Theoretical Economics, 11(3), 1053-1102.

Kregor, B., 2015. Food trucks, incremental innovation, and regulatory ruts. U. Chi. L. Rev. Dialogue, 82, p.1.

Krueger, N. F., Reilly, M. D., \& Carsrud, A. L. (2000). Competing models of entrepreneurial intentions. Journal of Business Venturing, 15(5), 411-432.

Kuratko, D. F. (2011). Entrepreneurship theory, process, and practice in the 21st century. International Journal of Entrepreneurship and Small Business, 13(1), 8-17.

Lefebvre, V. M., De Steur, H., \& Gellynck, X. (2015). External sources for innovation in food SMEs. British Food Journal, 117(1), $412-430$.

Martin, N. (2014). Food fight! Immigrant street vendors, gourmet food trucks and the differential valuation of creative producers in Chicago. International Journal of Urban and Regional Research, 38(5), 1867-1883.

McLaughlin, K., 2009. Food truck nation. Wall Street J The Companynal Online, 5. Retrieved from https://doc.uments.com/hfood-truck-nation.pdf. Last access July 2018

Miles, M. B.; Huberman, A. M., 1994. Qualitative data analysis: An expanded sourcebook. Washington DC, Sage Publications.

Moreira, D. A. (2004). Pesquisa em Administração: Origens, usos e variantes do método fenomenológico. Revista de Administração e Inovação, 1(1), 2004.

Morelix, A., Fairlie, R. W., \& Tareque, I. (2017). 2017 Kauffman index of startup activity: Metropolitan area and City Trends.

National Restaurant Association, 2011. Chef Survey: What's hot in 2011. Retrieved from http://www.restaurant.org/Downloads/ PDFs/News-Research/whats hot 2011.pdf . Last access May 2018

Nooteboom, B., 1993. Schumpeterian and Austrian entrepreneurship: a unified process of innovation and diffusion. Rijksuniversiteit Groningen, Faculteit Bedrijfskunde.

Ozaralli, N., \& Rivenburgh, N. K. (2016). Entrepreneurial intention: Antecedents to entrepreneurial behavior in the USA and Turkey. Journal of Global Entrepreneurship Research, 6(1), 3.

Reynolds, P.D., Bygrave, W.D., Autio, E., Cox, L.W. and Hay, M., 2002. Global Entrepreneurship Monitor Executive Report. Kauffman Center for Entrepreneurial Leadership at the Ewing Marion Kauffman Foundation, Kansas City, MO.

Rishi, K. L., 2013. A Food (R)evolution: A look at how mobile food is changing Los Angeles. Urban \& Environmental Policy, Institute Occidental College. Retrieved from https:/www.oxy.edu/sites/default/files/assets/UEP/Comps/2013/ Rishi\%20Kiran_A\%20Food\%20Revolution\%2D\%2DComps\%20Final\%20Draft.pdf. Last Access Mar 2018

Ryan, B., \& Gross, N. C. (1943). The diffusion of hybrid seed corn in two lowa communities. Rural Sociology, 8(1), 15.

Schumpeter, J.A., 1961. Teoria do desenvolvimento econômico. Fundo de Cultura.

Shi, H. X., \& Dana, L. P. (Eds.). (2013). Market orientation and entrepreneurship in Chinese family business: A socialisation view. International Journal of Entrepreneurship and Small Business, 20(1), 1-16.

Shin, Y. H., Kim, H., \& Severt, K. (2018). Antecedents of consumers' intention to visit food trucks. Journal of Foodservice Business Research, 21(3), 239-256.

Sundbo, J. (1997). Management of innovation in services. Service Industries Journal, 17(3), 432-455.

Tiwari, P., Bhat, A. K., \& Tikoria, J. (2017). An empirical analysis of the factors affecting social entrepreneurial intentions. Journal of Global Entrepreneurship Research, 7(1), 9.

Vedana, S.N., Paslauski, C.A., Roos, E.C., Schiavi, C.S. , 2015. Comida em Movimento: o significado simbólico dos eventos gastronômicos de rua e food trucks em Porto Alegre. In: XXXIX Enampad - Encontro da Anpad, Belo Horizonte, MG.

Vrontis, D., Thrassou, A., Santoro, G., \& Papa, A. (2017). Ambidexterity, external knowledge and performance in knowledgeintensive firms. The Journal of Technology Transfer, 42(2), 374-388.

Wennekers, S., \& Thurik, R. (1999). Linking entrepreneurship and economic growth. Small Business Economics, 13(1), 27-56.

Williams, C. C., \& Gurtoo, A. (2012). Evaluating competing theories of street entrepreneurship: Some lessons from a study of street vendors in Bangalore, India. International Entrepreneurship and Management Journal, 8(4), 391-409.

Williams, C.T., 2012. A hungry industry on rolling regulations: A look at food truck regulations in cities across the United States. Me. L. Rev., 65, p.705.

Yin, R. K. (2017). Case study research and applications: Design and methods (6th ed.). Sage publications.

Zhang, J.A., Chen, G., and Kane, C.O., 2018. External Network Ties, Entrepreneurial Orientation and Innovation Performance. Academy of Management Proceedings. Vol. 2018, No. 1.

Zhang, J.J., Groen, A.J., and Belousova, O., 2018. Innovation failure and innovation direction change in entrepreneurial firms. Academy of Management Proceedings. Vol. 2018, No. 1. 